UCRL-91257

FREPRINT

CONF $-8411 / 60--1$

\author{
Laboratory Experiments Designed to Provide \\ Limits on the Radionuclide Source Term \\ for the NWWS Project
}

V. M. Oversby

R. D. McCright.

Proceedings of Workshop on the Source Term

for Radionuclide Migration from HLW

or Spent Nuclear Fuel

Albuquerque, NM

November $13-15,1984$
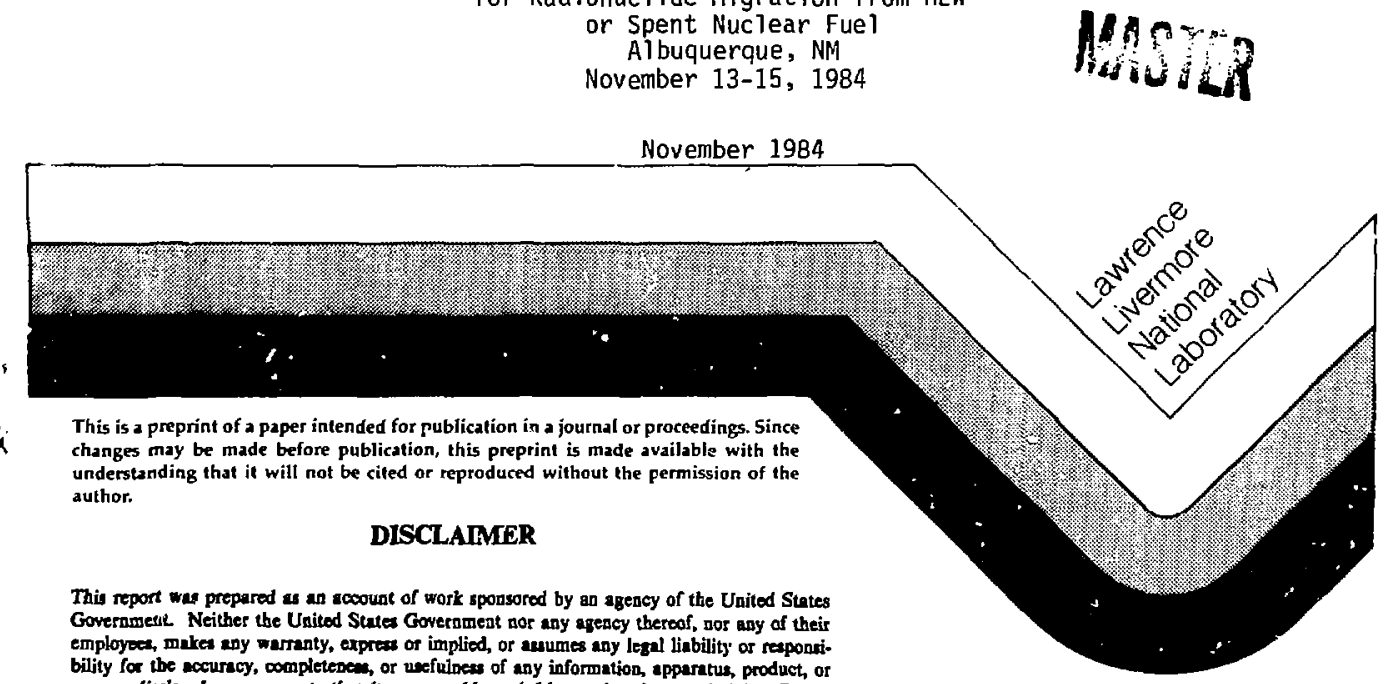

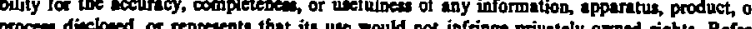
ence berein to any specific commercial product, process, or ervice by trade name, trademark, manufacturer, or ofberwhe does not necemarily constitute or imply its endorsemenh rocommendation, of favorily by the Uniled States Government or any arency theroof. The views

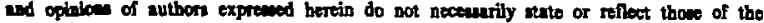
United Staten Gomarnment or any asency thercol. 
UCRL--91257

DE85 009952

\title{
LABORATORY EXPERIMENTS DESIGNED TO PROVIDE LIMITS ON THE RACIONUCLIOE SOURCE TERM FOR THE MHWSI PROJECT
}

\author{
V. M. Qversby and R. D. McCright \\ Lawrence Livermore National Laboratory \\ Livermore, California 94550 USA
}

\begin{abstract}
The Nevada Nuclear Waste Storage Investigations Project is investigating the suitability of the tuffaceous rocks at Yucca Mountain Nevada for potential use as a high levei nuclear waste repository. The horizon under investigation lies above the water table, and therefore offers a setting that differs substantially from other potential repository sites. The unsaturated zone environment allows a simple, but effective, waste package design. The source term for radionuclide release from the waste package will be based on laboratory experiments that determine the corrosion rates and mechanisms for the metal container and the dissolution rate of the waste form under expected long term conditions. This paper describes the present status of laboratory results and outlines the approath to be used in combining the data to deve?op a realistic source term for release of radionuclides from the waste package.
\end{abstract}

\section{RÉSUMÉ}

"The Nevada Nuclear Waste Storage Investigations Project" est en train d'étudier la pertinence des rochers en tuf dans la montagne Yucca en Hevada pour son utilisation possible pour le stockage définitif des déchets radioactives. Le terrain, sous investigation, se situe au-dessus de la nappe aquifére et offre donc un emplacement qui différe notablement d'autres lieux de stockages possibles. Ce'cte zone d'environnement non-saturé nous permattrait de désigne, un conteneur simple et á la fois effectif. La "source term" pour l'émission de radionucléides du conteneur des déchets se sera basée sur úes experiences de laboratoire qui détermineront le taux de corrosion et les mécanismes nécessaires au conteneur métallique, ainsî que le taux de dissolution des déchets dans des conditions prévisibles á long termes. Ce papier décrit le statut présent des résultats de laboratoire et décrit l'approche qu'on utilisera en combinant toutes les données pour développer une "source term" réaliste aux fins de minimiser la rélâche de rífionucléides du conteneur fec déchets. 


\section{INTRODUCTION}

The Nevada Nuclear Waste Storage Investigations Project is studying the tuffaceous rock formations at Yucca Mountain, Mevada, to determine the suitability of these rocks for construction of a high level nuclear waste repesitory. The horizon that is under investlgation is the Topopah Spring Member of the Paintbrush Tuff, a welded, devitrified ash flow tuff. At Yucca Mountain, this unit lies in the unsaturated zone. The water table is approximately $150 \mathrm{~m}$ below the potential repository horizon in the center of the repository exploration block.

The unsaturated setting results in several conditions that are different from the more familiar circumstances for a repository designed for siting below the water table. Some of the important design considerations for the unsaturated zone include:

(1) The waste package will not be in contact with standing water under anticipated conditions;

(2) The waste package will not be subjected to lithostatic or hydrostatic load;

(3) The maximum temperature of liquid water that can contact the waste package is determined by the unconfined boiling point of water at the appropriate elevation $\left(95^{\circ} \mathrm{C}\right.$ at Yucca Mt.);

(4) Water influx will be limited to that avai?able through downward infiltration (rainfall minus evapotranspiration);

(5) The waste packages will be in contact with air;

(6) Container and waste form degradation will occur in air-steam and dripping water environments.

\section{WASTE PACKage ENVIRONMENT and haSTE PACKAGE DESIGN}

The welded, devitrified sections of the Topopah Spring tuff consist of a fine grained intergrowth of quartz, cristobalite, and alkali feldspar. with a smail proportion of phenocrysts. Phenucryst minerals are quartz. alkali feldspar, piagioclase, and biotite [1]. Sampies of water have not been obtained yet from the unsaturated zone tuff ot the repository level; these samples will be obtained during the construction of the exploratory shaft. Pending availability of unsaturated zone water samples, the water from Heil $\mathrm{J}-13$, which is 1ocated several miles to the east of Yucca Mt., has seen adopted as the reference ground water for NNWSI experimental work. The well is at a lower elevation than Yucca Mt. and the Topopah Spring tuff, which is below the water table at this elevation, is the major producing horizon for the well.

Experiments have been conducted to determine the potential changes in water chemistry due to interaction of the rock with $\mathrm{J}-13$ water at elevated temperatures [2]. The expected upper limit temperature for liquid water in macroscopic openings at Yucca Mt. is $95^{\circ} \mathrm{C}$; however, the capillary forces in pores may allow rock and water to equilibrate at somewhat higher temperatures. To account for this possibility, the rock-water experiments have been conducted at temperatures of 90,120 , and $150^{\circ} \mathrm{C}$. A summary of the predicted steady-state water chemistry as a function of temperature is given in Table $\mathrm{I}$. The bicarbonate content of $\mathbf{j} \times 13$ water is approximate !y $140 \mathrm{ppm}$. Carbonate/bicarbonate following reaction with the rock depends on the partial pressure of carbor dioxide and the pH. The other anion components are those originally present in $\mathrm{J}-13$ water: $r=2 \mathrm{mg} / 1, \mathrm{Cl}=7 \mathrm{mg} / 1, \mathrm{NO}_{3}=9 \mathrm{mg} / \mathrm{l}$, 
and $\mathrm{SO}_{1}=18 \mathrm{mg} / \mathrm{l}$. There is no significant source of these anions in the rock. so concentrations are independent of temperature.

\section{TABLE I: Estimate of Steady State Hater Chemistry for Topopah Spring} Tuff and $\mathrm{j}-13$ Water as a Function of Temperature

\begin{tabular}{|c|c|c|c|c|}
\hline Element & $25^{\circ} \mathrm{C}$ & $\begin{array}{l}\text { trat loo } \\
90^{\circ} \mathrm{C}\end{array}$ & $\begin{array}{l}/ 1 \text { at } \\
120^{\circ} \mathrm{C}\end{array}$ & $150^{\circ} \mathrm{C}$ \\
\hline $\begin{array}{r}\mathrm{Al} \\
\mathrm{B} \\
\mathrm{Si} \\
\mathrm{Ca} \\
\mathrm{Mg} \\
\mathrm{K} \\
\mathrm{Na}\end{array}$ & $\begin{array}{r}0.01 \\
0.13 \\
27 \\
12.5 \\
1.9 \\
5.1 \\
44\end{array}$ & $\begin{array}{r}0.4 \\
0.1 \\
49 \\
8 \\
0.2 \\
9 \\
40\end{array}$ & $\begin{array}{r}1.2 \\
0.1 \\
81 \\
3.5 \\
0.1 \\
9 \\
45\end{array}$ & $\begin{array}{r}0.1 \\
122 \\
3 \\
0.1 \\
9 \\
40\end{array}$ \\
\hline
\end{tabular}

The maximum amount of water that can contact a waste package in a fixed time interval is a function of the infiltration rate and the area of repository rock that channels water flow past the waste package. For vertical emplacement of waste packages in boreholes in the floor of drifts, the naximum water drainage can be reasonably estimated by considering a unit cell of the drift to be associated with each waste package. For a drift width of $6.1 \mathrm{~m}$ and package borahole spacing along the drift floor of 5 to $8 \mathrm{~m}$, the average drift area per package would be $40 \mathrm{sq.m}$. The water influx to that area would be 401 per year for an infiltration rate of $1 \mathrm{~mm} / \mathrm{y}$, the expected upper 1 imit under normal conditions at Yucca Mt.[3]. By contrast, if only the water that flows directly downward onto the top of a borehole can enter that emplacement hole, the $1 \mathrm{~mm} / \mathrm{y}$ infiltration rate would deliver only 0.51 of water to the borehole. In order to investigate the effects of higher infiltration rates, we will use 1,2, and $8 \mathrm{~mm} / \mathrm{y}$ as cases for release rate scenario analysis.

Analysis of the waste package environment described above has led to the following reference waste package design for NNWSI. The design for spent fuel consists of a $70 \mathrm{~cm}$. OD container fabricated from austenitic stain?ess steel [4]. The container thickness is $1 \mathrm{~cm}$. An internal space frame will be used to separate intact fuel assemblies or consolidated bundles of fuel pins. The reference emplacement conditions are vertical emplacement in boreholes drilled in the floor of emplacement drifts. No backfill or packing material is used around the waste packages. Reprocessed borosilicate glass waste forms from West Valley or from the Defense Waste Processing Facility would be placed in an overpack that would be similar to the spent fuel outer container. These reprocessed waste forms contain lower amounts of heat-producing radionuclides than spent fuel and are expected to be less complicated than spent fuel from the point of view of developing a waste package jource term. The remainder of this paper will consider only the source term for spent fuel.

The reference waste package design for spent fuel assumes that the fuel is 10 years out of reactor and had an average burnup for PWR fuel of $33,000 \mathrm{HWd} / \mathrm{MTH}$. Figure 1 shows the thermal history for a waste package containing consolidated fuel pins from six PWR assemblies with a total thermal output of $3.3 \mathrm{~kW}$. The emplacement conditions used in the calculation were vertical emplacement with $5 \mathrm{~m}$ package pitch and $47 \mathrm{~m}$ drift pitch. This produces an average thermal loading on emplacement of $48.4 \mathrm{~kW}$ per acre. The 
peak temperature for the spent fuel would be approximately $320^{\circ} \mathrm{C}$, while the Canister surface experiences a peak temperatlite of somewhat less than $250^{\circ} \mathrm{C}$. The host rock temperature for a distance of more than 1 meter around the borehole remains above $100^{\circ} \mathrm{C}$ for more than 1000 years under these emplacement conditions. Because the temperature surrounding the borehole is above the bolling point of water, the expected conditions for the waste package during the first 1000 years would be an atmosphere of alr saturated with water vapor at the appropriate temperature. After the temperature drops below the local boiling point of water, liquid water might contact the container. For waste packages that contain lower thermal loading or are at the edge of the repository the time of first ingress of liquid water into the borehole would be expected to be earlier than for the conditions used in the example above.

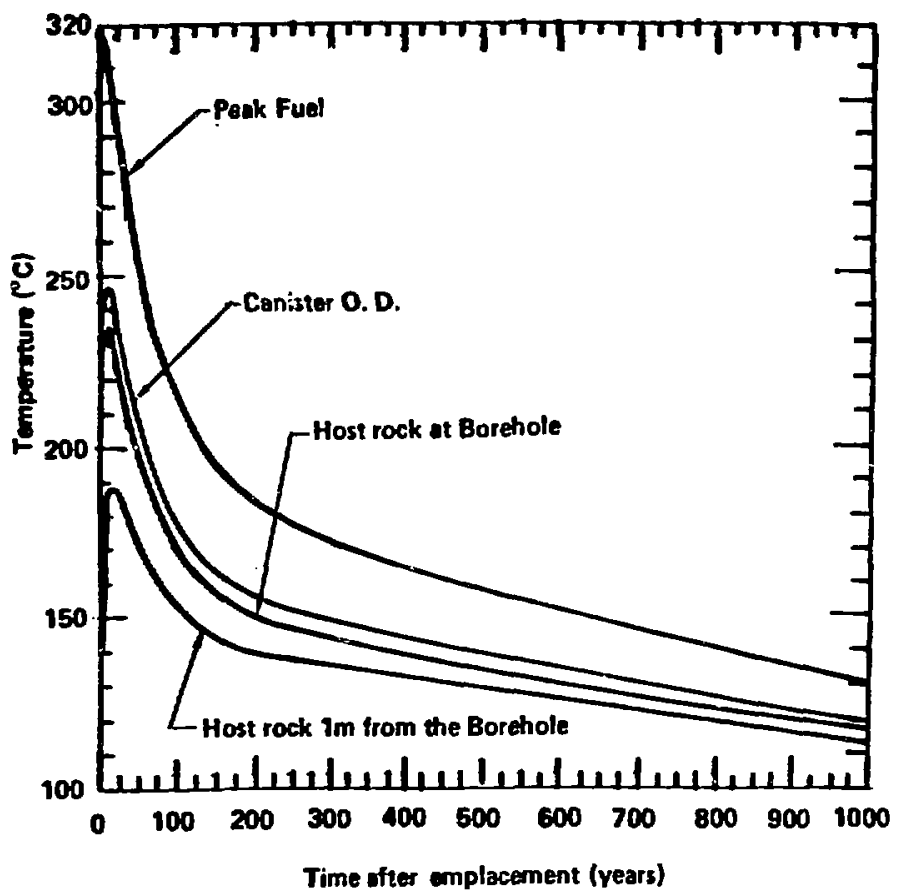

Figure 1: Thermal history for reference waste package.

CONTAINER CORROSION RATES AND MECHANISMS

The reference container material for NNWSI waste packages is austenitic stainless steel. Several grades of stainless steel are unjer investigation, including 304L, 316L, 317L, 321, 347, and high-nickel stainles 5 alloy 825 . Of these materials, the laboratory work has emphasized $304 \mathrm{~L}$ and 
316L. Hidespread industrial use of these grades indicates. that they perform well in oxidizing conditions and, therefore, they are promising candidate materials for nuclear saste containers in an unsaturated tuff repository. The results of experiments conducted to determine the general corrosion rate of these materials immersed in $\mathrm{J}-13$ water in the 50 to $100^{\circ} \mathrm{C}$ range indicates that the rate is essentially independent of temperature and the corrosion is uniformly distributed over the exposed surface area [5]. There was no significant difference in corrosion rates measured for $304 \mathrm{~L}, 316 \mathrm{~L}$, and $317 \mathrm{~L}$ in $50,70,80,90$ and $100^{\circ} \mathrm{C} \mathrm{J}-13$ water at exposure times of 3548 and 5000 hours. The grand average of data gave a corrosion rate of $0.19+1-0.04 \mu \mathrm{m} / \mathrm{y}$. If more recently obtained daty for 7500 hours of exposure are included in the average, the rate is $0.15+/-0.036 \mathrm{\mu m} / \mathrm{y}$. The total range of measured corrosion rates in this series of experiments was 0.025 to $0.36 \mu n / y$.

Published [6] and unpublished results of testing of these materials in $100^{\circ} \mathrm{C}$ saturated steam (7500 exposure hours) gave a range of corrosion rates of 0.037 to $0.31 \mu \mathrm{m} / \mathrm{y}$ and an average of $0.16+/-0.03 \mu \mathrm{m} / \mathrm{y}$. Oxidation rates ranging from 0.00 ? to $0.008 \mu \mathrm{m} / \mathrm{y}$ have been measured in $150^{\circ} \mathrm{C}$ unsaturated steam ( 3800 exposure hours). As expected, the rates under "wet" steam conditions overlap those from the fully immersed conditions, while the rates obtained inder "dry" steam conditions are substantially lower. Tests conducted in the presence of gamma radiation qive similar results to those without radiation.

As discussed above, the exact temperature history of a waste package deperids on its position in the repository layout and on the thermal loading of the package. In fact, these parameters are themselves interdependent. An exact description of the layout and package thermal loadings is not possible until the operations stage of repository development when shipping information from waste producers is available. To allow for the uncertainties in these parameters, we have chosen to use the $100^{\circ} \mathrm{C}$ air/steam data to represent the corrosion rate for $h i g h e r$ temberatures. Since these data are comparable to the data for inmersed conditions, we will use the grand average of the immersed carrosion data to estimate the waste package 1 ifetime under the assumption that uniform corrosion is the service limiting degradation mode.

The only indications of localized corrosion that have been observed to date for $304 \mathrm{~L}, 316 \mathrm{~L}$, and $317 \mathrm{~L}$ occurred at $100^{\circ} \mathrm{C}$ and consisted of enhanced corrosion at the site of artificially induced crevices that were created underneath Teflon washers. The highest rate of preferential attack was about $0.3 \mathrm{um} / \mathrm{yr}$ after 7500 hours of exposure. No preferential attack was observed at $90^{\circ} \mathrm{C}$ and lower temperatures for these materials.

The other corrosion mechan ism of concern for waste packages is intergranular stress corrasion cracking (IGSCC). Occurrence of IGSCC requires attainment of three concomitant conditions: (1) development of a continuously sensitized ( $\mathrm{Cr}$ depleted) microstruciure along grain boundaries; (2) the presence of a sufficiently aggressive corrosion environment to attack the Cr-depleted regions and initiate a crack; and (3) a stress level above a critical threshold to propagate the crack. This level is usually on the order of $70 \%$ of the yield strength. While waste package designs and container fabricition process specifications will ensure that the operating and residual stress levels are kept well below this threshold, it is instructive to determine whether the container allay could become sensitized under the long term thermal conditions in the repository. 
Figure 2 shows the temperature history for a waste package contalning consolidated rods from BWR assemblies plotted as tine vs $1 / T$ (thermal data from [7]). The ilne for $304 L$ sensitization was obtained by extrapolation of data obtained at higher temperatures $\left(450-750^{\circ} \mathrm{C}\right)$. This particular material had a carbon content $(0.028 \%)$ near the top of the permitted range and was heavily cold-worked [8]. Both of these conditions enhance susceptibility to sensitization. The offset of the waste package cooling curve from the sensitization line suggests that long-term, low-temperature sensitization of even heavily cold-worked material should not be of concern. Additional conservatism can be incorporated into the container materiai selection, however, as illustrated by the line for non cold-worked $316 \mathrm{LN}$ stainless steel [9]. Additions of nitrogen and molybdenum in the $316 \mathrm{LN}$ retard the diffusion of carbon in austenitic structures and therefore reduce the susceptibility to sensitization. Figure 2 further illustrates that experiments can be perforned at 250 to $400^{\circ} \mathrm{C}$ for one to a few years in duration to confirm the predictions on sensitization made from the higher temperature extrapolations discussed above.

The data available on corrosion in the environment anticipated at Yucca Mt. indicate that uniform corrosion is the most likely mechanism for container degradation. Extrapolation of the data for the average uniform corrosion rate $(0.15 \mathrm{un} / \mathrm{yr})$ to obtain the time necessary to corrode through $1 \mathrm{~cm}$ of metal gives a predicted package lifetime of 67,000 years. Crevice corrosion under saturated steam conditions at $100^{\circ} \mathrm{C}$ would reduce this lifetime somewhat. The duration of experiments is presently limited to under one year ( $7500 h=312.5$ days) and more data is required to determine that increased corrosion rates do not occur following prolonged exposure. Present results, however, indicate that failure of the metal container in times less than 10,000 years will be an unlikely event. Potential causes of premature breach of the metal container could include defective closure welds that are not detected during weld inspection and portions of the container being highly stressed due to some off-normal fabrication condition. These are considered to be low probability conditions; however, the consequences of these conditions are being evaluated as part of the metal corrosion testing program.

\section{SPENT FUEL DEGRADRTION RATE}

Light water reactor fuel generally consists of $\mathrm{UO}_{2}$ pellets containes in Zircaloy cladding. A small percentage of fuet is clad in stainless steel. For simplicity, we will confine discussion to Zircaloy clad fuel. A similar treatment will apply to stainless steel clad fuel.

At the end of its useful life, most spent fuel cladding is intact; a small percentage of cladding will have developed a breach during reactor service. Fuel designs and reactor operating conditions used during the 1960's led to development of pin hole or crack defects in several percent of the pins. More recent designs and operating conditions result in far fewer defects in the cladding. The defect population for fuel presently in use has been estimated to be about $0.1 \%$ or less $[10]$.

We are investigating the corrosion rates and mechanisms for Zircaloy under expected disposal conditions for a repository in tuff. Preliminary analysis indicates that the dominant corrosion mechanism will be stress corrusion cracking. Degradation by uniform corrosion or pitting corrosion is expected to be minor [11]. Experiments are currently under way to measure the 
rate of uniform and non-uniform corrosion of irradiated Zircaloy. Results of these experiments will be used to determine the rate of defect generation in the spent fuel cladding population. Experiments are also being conducted on spent fuel oxidation rates since fuel oxidation through small cladding defects might result in an increased rate of cladding degradation.

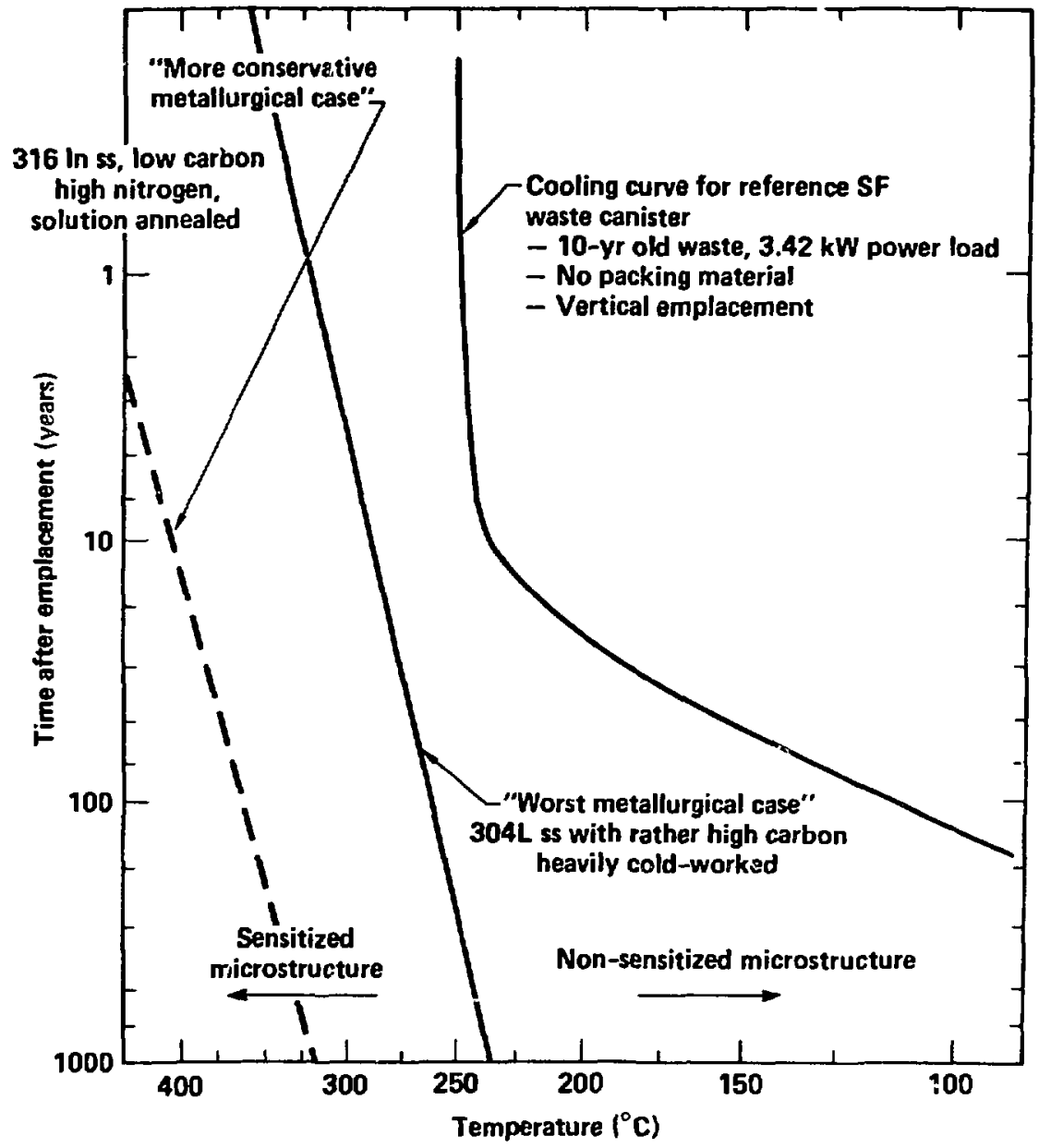

Figure 2: Relationship between thermal history of emplaced nuclear waste container and long-term sensitization in austenitic stainless steels. 
Leaching of radionuclides from spent fuel can occur only after the cladding is breached and water or air can contact the fuel. In most cases, contact of fuel with water will occur through small defects in the cladding. In some cases, the cladding may split and expose the fuel pellets directly to water. To cover the possible geometric configurations for fuel-water contact, we are conducting spent fuel dissolution studies that use four fuel conditions: (1) bare fuel plus the cladding from which the fuel was removed, (2) a fuel segment approximately five inches long, end capped with water tight fittings, and no defects induced in the cladding, (3) specimen similar to number 2, but with a laser drilled hole in the cladding, and (4) specimen similar to number 2, but with a slit machined in the cladding. Specimen 2 provides an indication of the surface contamination of the cladding. Such contamination may occur during reactor service, pool storage at the reactor, or during preparation of the specimens for testing. Details of the experimental procedure are given in reference [12].

The first series of spent fuel tests were conducted in deionized water at ambient hot cell temperatures and used Turkey Point PWR fuel. Solution samples (generally $10 \mathrm{ml}$ ) were taken periodically and fresh deionized water added to the test vessel to return the volume to $250 \mathrm{ml}$. The test was run for approximately 9 months, temporarily terminated to allow transfer of the fuel test specimens to new reaction vessels, and then restarted in fresh deionized water. Results for uranium in solution samples for the first sixty days of the first cycle of the test are shown in Figure 3, along with results for a similar series of tests using $\mathrm{J}-13$ water and H.B. Robinson PWR spent fuel. The solution concentration that would be produced if one part in $10^{5}$ of the inventory present in the test were dissclved is shown for reference for each test. Details of results for the deionized water tests are contained in reference [13] and for the J-13 water tests in reference [14].

The bare fuel sample, deionized water showed an initial pulse of $U$ release followed by a rapid decrease of $U$ in the solution. Subsequent testing showed that the $U$ was not in true s. ution, but was contained in particles 1 arger than $0.4 \mu \mathrm{m}$ in size. The concentration of other elements in the solutions, such as $\mathrm{Pu}$, indicated that the initial pulse of release was due to suspension of very fine particles of fuel that rapidly settled out and plated out onto the reaction vessel surface. Analysis of acid rinse solutions of the test yesseis after initial termination of the test gave compositions that indicated plate-out of material with an inventory of elements that would be expected in bulk spcnt fuel. When the tests were restarted with fresh deionized water, another pulse of release was observed, but it was substantially smaller than the first pulse. Release from specimens with induced cladding defects did not show an initial pulse of release, and resulted in solution concentrations that were one or two orders of magnitude lower than for the bare fuel. Eventually the particulate $U$ settled out and final solution concentrations were similar to those found for the intact control s-mple. Settling time for the initial test was over 8 months, while in the restarted test settling occurred after only 4 months. The amount of uranium present in true solution or in particles smaller than 0.4 um was only a few ppb in all tests in deionized water.

Results for testing of bare fuel in $\mathrm{J}-13$ water also show an initial pulse of release that is similar in magnitude to that observed in deionized water. In this case, the uranium becomes complexed with carbonate in the solutions and is present as a true solution species. The uranium 


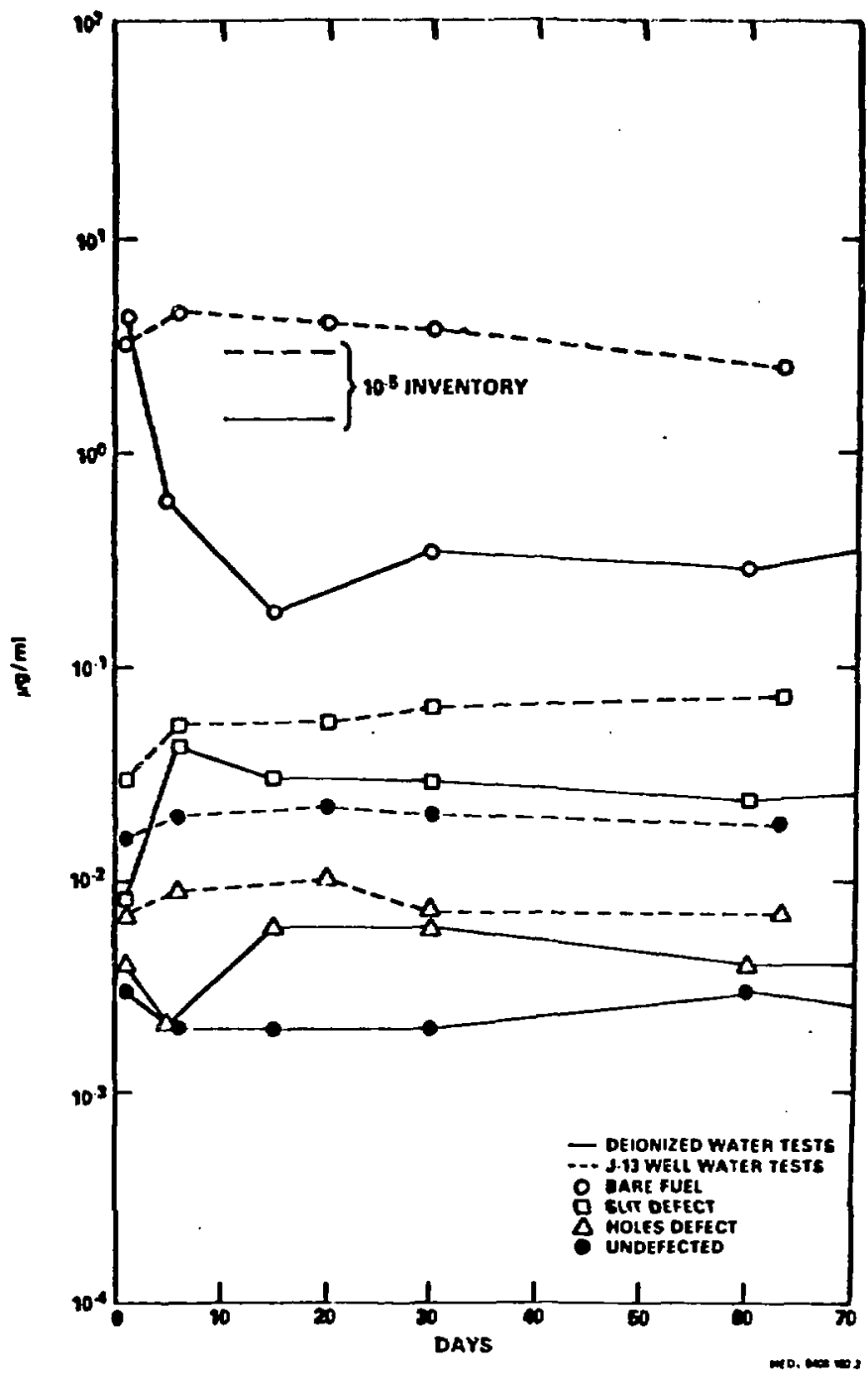

Figure 3: Uranium in unfiltered solutions from testing of PWR spent fuel. See text for details. 
concentration decreases slowly as the test progresses. This may be due to removal of some of the initial "pulse" material as analytical samples are taken that is not replaced by further spent fuel reaction. The control sample (marked undefected) shows $U$ at levels between that of the laser hole and slit defert samples. This indicates a small amount of residual contamination on the control sampie, amounting to about 5 micrograms of $U$. The J-13 water tests are still in progress and will follow a test plan simflar to that for the deionized water tests. A second series of tests using Turkey Point fuel in $\mathrm{J}-13$ water is also in progress. Tests using $\mathrm{H}$. B. Robinson fuel and $\mathrm{J}-13$ water under higher temperature conditions are planned.

Some radioactive species in spent fuel are concentrated in the gap between the pellet and cladding and/or on the grain boundartes of the fuel. These species became segregated during reactor operation and lie in regions that allow them to be released to solution at a rate faster than the matrix fuel dissolves. Cesium, iodine, and possibly technetium, show an initial release rate that is high compared to the $U$ release and that correlates wich the content of fission gas in the pellet-cladding gap $[13,15]$. The amount of cesium and similar species that is contained in the highly mobile fraction is usually less than $1 \%$ of the inventory in the pin [10]; the remainder is oispersed through the fuel matrix and should be released at the same rate as the matrix dissolves. For the tests discussed above, Cs release from bare fuel was essentially instantaneous and corresponded to about $0.2 \%$ in the Turkey Point tests in either solution and about $0.6 \%$ in the $H$. B. Robinson tests. In the deionized water tests the release of Cs from slit and hole defects was slower but eventually reached the same levels as the bare fuel initial reiease. On restarting the deionized water tests, an additional rapid release was seen; however, the amount of release was smaller than for the first contact with water.

A third source of radioactivity in spent fuel exists in the metal components of the fuel assembly. Neutron activation products are formed in the fuel cladding and in the metal assembly spacers and grids. For steel components, the corrosion rates will probably be similar to those determined as part of the container corrosion testing. This will be checked by a limited series of experiments on fuel assembly parts. The main long-lived radionuclides containeo in the steel components will be nickel isotopes.

The most significant radionuclide present in the cladding is $c-i 4$. It is formed by the reaction $N-14(n, p) C-14$. Experiments conducted at temperatures of about $275^{\circ} \mathrm{C}$ have shown that approximately $0.2 \%$ of the inventory of $\mathrm{C}-14$ froin a fuel assembly can be released into an air atmosphere within about one month [16]. The process involved in the release is thought to be removal of carbon froin the oxidized skin of the Zircaloy cladding by reaction of the oxygen in the atmosphere with the carbon in the cladding oxidation layer to release $\mathrm{CO}_{2}$. The proposed mechanism will be checked by experiments conduc'.ed under controlled conditions using defueled cladding. Further release of $[-14$ from the Zircaloy is much slower than the initial release from the oxidized layer, and will probabiy be controlled by the rate of oxidation of the Zircaloy. Since this rate is very low at low temperatures, release of $C-14$ will probably be slow after the initial oxide layer carbon has been removed.

The experiments described above result in a source term for spent fuel that will be composed of at least four componenis thai are released at 
different rates. The parts will consist of

(1) Elements whose release is controlled by matri: dissclution:

(2) Elements present in part in the pellet-cladding gap;

(3) Elements contained in stainless steel spacers and grids;

(4) Elements contaired in the fuel cladding.

A separate dissolution/degradation rate will be determined for each of these components of the source term.

\section{WASTE PACKAGE SOURCE TERM DEVELOPMENT}

Data from the experiments described abcve will be tosed to develop the model for release rate of radianuclides from the waste pirikage as a function of time. A distribution iunction will be developed for container breach that includes both expected conditions and off-normal conditions. Datc presently available suggest that breach uf a container earlier than 50,000 years after disposal would not occur under anticipated conditions.

The container breach-tine distribution will give the starting point for radionuclide release from the waste package. The first radionuc: ide. released would be $\mathrm{C}-14$ from the oxidized outer layer of the Zircaioy cladding. This release does not require contact of water with the fuel. Following container breach, water might enter the container. Tha geometric description of the breached container and the expected yater fow rate will be used to determine the appropriate witer to fuel ratio to bo used in modelling the oreached container. Present data indicate that infiliration rates of 0.1 to $8 \mathrm{~mm} / \mathrm{y}$ should cover the range of lizely conditions.

A waste package with one or more cracks is the most likely form of a breached container. Depending on the location of the cracks, infiltrating water might collect to some depth in the container. For the purposes of initial source term modelling, we will assume that two cracks exist with both cracks near the top of the container. The volume of a container is less then 18001 , while the weight of spent fuel in the container is about $3100 \mathrm{~kg}$. More than half of the volum? wil! be occupied by the fuel, so the maximum water to fuel ratio would be about $0.31 / \mathrm{kg}$. The spent fuel dissolution studies described above use water to fuel ratios of 3 to $101 / \mathrm{kg}$. it is unlikely that we will be able to conduct experiments at a water/fuel ratio as low as 0.3 ; however, we will establish dissolution rates over a range of water/fuel ratios so that extrapolation to the appropriate value can be made.

The source term will include an estimate of the rate of degradation of the Zircaloy cladding. Spreading the breach of cladding over a range of time has a large effect on the release rate of elements contained in the pellet-cladding gap. If the ciadding fails at a uniform rate over 2000 years, a rapis release of $1 \%$ of the iodine on breach of cladding would become a population release rate of 0.5 parts in $10^{5}$ of the iodine inventory due to that mechanism. The total release rate of-iodine would then be found by summing the parts due to the rapid release fraction and that due to matrix dissolution.

The Zircaloy, stainless steel, and spent fuel dissolution and degradation rates will then be used to determine the concentrations of radionuclides iis the water contained within a breached waste package. This information, then combined with the water infiltration rate, will then provide the volume of water containing radionuclides that is displaced from the breached container annually, and the radioactive inventory contained in that 
water. This calculation will provide the source term for radioactive release from the waste package.

\section{REFERENCES}

[1] Bish, 0.L. et a 1.: "Preliminary Stratigraphic and Petrologic Characterization of Core Samples from USW-G1, Yucca Mountain, Nevada". Los Al amos Nat1. Lab. LA-8840-MS, 1981.

[2] Oversby, V. M.: "Reaction of the Topopah Spring Tuff with J-13 Water at $120^{\circ} \mathrm{Cm}$, Lawrence Livermore Nat1. Lab. UCRL-53574, 1984.

[3] Moitazer, P. et al.: "Drilling, Instrumentation, and Preliminary Testing Results of Borehole USW UZ-1 Penetrating Thick Unsaturated Tuffs, Nevada Test Site", U.S. Geological Survey, USGS-WRI-84-x, 1984(in prep.).

[4] O'Neal, W.C. et al.: "Preclosure Analysis of Conceptual Waste Package Designs for a Nuclear Repository in Tuff", Lawrenc: Livermore Nat1. Lab. UCRL-53595, 1984 .

[5] Glass, R.S. et ai.: "Electrochemical Determination of the Corrosion Behavior of Candidate Alioys Proposed for Containment of High Level Haste in Tuff", Lawrence Livermore Natl. Lab. UCID-20174, 1984.

[6] McCright, R.D. et al.: "Selection of Candidate Canister Materials for High-Level Nuclear Waste Containment in a Tuff Repository", Lawrence Livermore Nat 1. Lab. UCRL-89988, 1983.

[7] Hockman, J. N. and W. C. O'Neal: "Thermal Modeling of Nuclear Waste Package Designs for Disposal in Tuff", Lawrence Livermore Nat1. Lab. UCRL-89820 Rev. 1, 1984.

[8] Fox, M.J. and R. D. McCright: "Än Overview of Low Temperature Sensitization", Lawrence Livermore Nat1. Lab. UCRL-15619, 1983.

[9] Mulford, R.A., et a].: "Sensitization of Austenitic Stainless Steels II: Commercial Purity Alloys", Corrosion 39, 132, 1983.

[10] Hoodley, R.E.: "The Characteristics of Spent LWR Fuel Relevalit to its Storage in Geologic Repositories". Westinghouse Hanford Co. HEDL-TME 83-28, i 983.

[11] Rothman, A.J.: "Potential Corrosion and Degradation Mechanisms of Zircaloy Cladding on Spent Nuclear Fuel in a Tuff Repository", Lawrence Livermore Nat1. Lab. UCID-26172, 1984.

[12] Wilson, C.N.: "Test p? fen for Spent Fuel Cladjing Containment Credit Tests", West inghouse Hanford Co. HEDL-TC-2353-2, 1983.

[13] Wilson, C.N.: "Results frmm NHWSI Series 1 Spent Fuel Leach Tests", Westinghouse Hanford Co. HEDL TME 84-30, 1984.

[14] Wilson, C.N. and V.M. Oversby: "Radionuclide Release from PWR Fuels in J-13 Wate: ${ }^{\prime \prime}$, Lawrence Livermore Nat1. Lab. UCRL-91464, 1984 (in prep.).

[15] Johnsun, I..H. et al.: "Relationship Between Fuel Element Power and the. Leaching of $137 \mathrm{Cs}$ and 129 I from Irradiated $00_{2}$ Fuel" Proc. of the ANS Topical Meeting on Fission Product Beharior and Source Term Research, Snowbird, Utali, July 1984.

[16] Van Konynenburg, R.A. et al: "Behavior of Carbon-14 in Waste Packages for Soent Fuel in a Repository in luff", Lawrence Livermore Natl. Lab. UCRL-90855, 1984.

*Work performed under the auspices of the U.S. Department of Energy by the Lawrence Livermore National Laboratory under contract number W-7405-ENG-48. 